\title{
Packaging based on Ag-Low Density Polyethylene for shelf-life extension of pasteurized and traditional butters at refrigerated temperature
}

\author{
Mobina POUYAMANESH ${ }^{1}$, Hamed AHARI²* (D), Amir Ali ANVAR ${ }^{1}$, Guity KARIM ${ }^{3}$
}

\begin{abstract}
This article focuses on increasing the shelf life of both pasteurized (Pa) and traditional (Tr) butters wrapped in Ag-Low Density Polyethylene (LDPE) film in concentration of 2.5\%, 7.5\%, 12.5\%, and 17.5\% at refrigerated temperature up to one month. Silver nanoparticles were synthesized $(20.63 \mathrm{~nm})$ through the chemical reduction followed by the melt mixing method to produce AgLDPE films. A mixed model-ANOVA Repeated Measurement presented that total bacteria, S. aureus and E. coli were eliminated from the Pasteurized butter samples wrapped with 17.5\% Ag/LDPE films. In comparison, psychrophilic bacteria can be eradicated by $2.5-17.5 \% \mathrm{Ag} / \mathrm{LDPE}$ films after 30d. Peroxide value showed a slight fall from 0.50 and $0.28 \mathrm{meq} / \mathrm{kg}$, respectively for Pa and Tr butters on the 1 st day in the control group to 0.31 and $0.24 \mathrm{meq} / \mathrm{kg}$, respectively in the butter wrapped with $17.5 \% \mathrm{Ag}-\mathrm{LDPE}$ film at the end of the storage with no significant difference $(\mathrm{p}>0.05)$ with other treatments. Iodine value was decreased after $30 \mathrm{~d}$. It is concluded that the use of $17.5 \% \mathrm{Ag} / \mathrm{LDPE}$ as a coating of butter can safely preserve pasteurized butter at least a month.
\end{abstract}

Keywords: butter; nano silver; chemical reduction; melt mixing; LDPE packaging.

Practical Application: Extending shelf life of butter using nanoparticles.

\section{Introduction}

Butter is a water-in-oil (W/O) emulsion produced by the inversion phase of cream, in which its proteins are the emulsifiers. Butter remains a stable compacted commodity when chilled (Schäffer et al., 2001) but must be liquid in blood for it to be safe for public health. Butter is one of the largest milk by-products. It is full rich in fatty acids and produced traditionally or industrially. Rancidity is a critical concern in butter preservation (Asdagh \& Pirsa, 2020).

Fluorescent illumination, temperature alteration, or sunshine result in the oxidative changes of fat and microbial spoilage in butter. Lipolytic enzymes could be excreted from psychrotrophic, Escherichia coli, and positive coagulase Staphylococcus aureus, which have spoilage impact on off-flavors in butter, and other dairy products that decrease the shelf life and the products become unhealthy and unfavorable for consumption (Tola et al., 2019).

In food safety disciplines, E. coli (Poolman \& Wacker, 2016) and S. aureus (Zhao et al., 2016) are hazardous foodborne pathogens, that have caused many public poisonings and should be diagnosed and controlled (Wei et al., 2018). E. coli is usually known as a pathogenic indicator organism since it is present in humans and, in particular, dairy animal ingesta, (Morgan et al., 2008), which are shed daily to the environment. Its presence in milk indicates faecal contamination (Elmonir et al., 2018) while $S$. aureus impurity of milk could be related to infected dairy animals, acting as carriers of the pathogen (Kadariya et al., 2014) or livestock staff, chiefly those with poor sanitation, especially for primitive livestock husbandry practices (Abebe et al., 2016). In subclinical mastitis, in lactating dairy animals, both pathogens are shed into the milk (Bihon et al., 2019) and the health of the consumers of this milk can be affected (Elmonir et al., 2018).

Proper packaging materials should have high blockade attributes to decrease the frequency of this inappropriate process and increase the declared shelf life (Karaman et al., 2015). Investigations have shown some successfulness in increasing the shelf life of butter. It can be packed in polypropylene or LDPE, in aluminium foils (Karaman et al., 2015), with a nanocomposite (NC), such as cellulose-based papers coated in chitosan-Ag/TiO2 (Apjok et al., 2019) or in form of active packaging layer integrating anti-pathogenic nanocomposite (NC) included herbal compounds (Karaman et al., 2015) or omega-3 (São José et al., 2019). Butter is also gamma irradiated which improve the quality and increase the shelf life of the product (Rady \& Badr, 2003). The first compounds applied as active packaging were organic acids, and non-degradable polymers. Currently, nanoparticles (NPs) have been extensively used with more benefits than other known combinations such as organic acids or enzymes due to high resistance to heat or severe chemical conditions (Simbine et al., 2019). Nanoparticles are suggested to have anti-microbial activity due to their prevention of aerobic respiration and damaging the DNA of pathogens (Shi et al., 2018), reactive oxidative stress on the cell membrane of bacteria, and binding to the cell membrane convinced by AgNPs (Yan et al., 2018). 
Based on the aforementioned references, the objective of our study was to increase the shelf life of both pasteurised and traditional butters using Ag-LDPE of different concentrations as films to cover the butter stored at a refrigeration temperature and analyze the bio-chemical parameters of the butters.

\section{Materials and methods}

\subsection{Preparation of silver nanoparticles (AgNPs)}

Silver nanoparticles were synthesized through the chemical reduction following the method of Vazquez-Muñoz et al. (2019). The $0.849 \mathrm{~g}$ of $\mathrm{AgNO}_{3}$ (Sigma-Aldrich Sydney, Australia) was dissolved in $50 \mathrm{~mL}$ of distilled water, and the solution was boiled. Trisodium citrate ( $1 \mathrm{gr}$ ) was then dissolved in $100 \mathrm{~mL}$ of distilled water. The $5 \mathrm{~mL}$ of the later solution were trickled to $100 \mathrm{~mL}$ of boiling $\mathrm{AgNO}_{3}$ solution and heated at $90{ }^{\circ} \mathrm{C}$ for 2 hours. It was then cooled at room temperature to give a reddish solution.

\subsection{Preparation of silver nanocomposite (NC) film}

Low Density Polyethylene (LDPE), with melt index of $25 \mathrm{~g} / 10 \mathrm{~min}\left(190^{\circ} \mathrm{C} / 2.16 \mathrm{~kg}\right)$ was prepared (Sigma-Aldrich $9002-88-4$, Germany). In order to stabilize the dispersity of particles into the LDPE matrix, nanosilver samples at concentrations of $0 \%$, $2.5 \%, 7.5 \%, 12.5 \%$ and $17.5 \%$ were dissolved in polyethylene glycol monostearate (PGE) (Sigma-Aldrich, Germany) using a sonication bath for $10 \mathrm{~min}$. Through the melt mixing process, the produced PGE-nanoparticles were exposed to the LDPE matrix at $130^{\circ} \mathrm{C}$ following the method of Jokar et al. (2012) with minor modification. A hot plate with a pressure of 45 bar was used at $135^{\circ} \mathrm{C}$ for $12 \mathrm{~min}$ to obtain square samples, followed by $12 \mathrm{~min}$ of cooling time according to the method of Jokar et al. (2012) with minor modifications. The Ag-NC packaging coatings were first cut to $5 \times 5 \mathrm{~cm}$ and sterilised by a UV lamp for $20 \mathrm{~min}$ before use.

\subsection{Scanning Electron Microscopy (SEM) test}

Morphology and size of Ag-NP was analyzed using scanning electron microscope (SEM, TESCAN, MIRA3, Brno, Czech Republic). The images produced in the composite field, in which a suspension was primarily prepared in an acetonitrile solvent in a lab Falcon and $3 \mathrm{~mL}$ of the resulting solution then placed on the adhesive base to evaporate the solvent. Subsequently, it was transferred to the Spotter coater and coated with gold exposed to argon gas for $10 \mathrm{~m}$. Ultimately, the final sample was placed into the chamber of the SEM and bombardment with fast electrons was done on the surface of the sample and images were recorded (Martins et al., 2012).

\subsection{Preparation of bacteria}

In the current study, the numeration of total viable bacteria, Escherichia coli (ATCC 25922), coagulase-positive (CP) Staphylococcus aureus (ATCC 9144), and psychrophilic bacteria was performed. The bacteria were prepared from the Iranian Research Organization for Science and Technology (IROST) and transferred to the laboratory of the Department of Food Science and Technology, IAU. The considered culture existed in plastic bead was added into a tube containing $5 \mathrm{~mL}$ of Nutrient Broth to revitalize the lyophilized bacteria by incubating at $37^{\circ} \mathrm{C}$ for 24-48 h. (Shrivash et al., 2018). The working stock culture was kept on tryptone soy agar at a refrigeration temperature.

\subsection{Preparation of butter samples}

Pasteurized and traditional butters were purchased from a pasteurized dairy company and a dairy retailer, respectively. They were transported to the laboratory under refrigeration temperature and then aseptically packed (10 g packages weighted from all parts of the surface, centre, and bottom of the butters) with $\mathrm{Ag}$ nanocomposites (Ag-NC) at $0 \%, 2.5 \%, 7.5 \%, 12.5 \%$ and $17.5 \%$ in triplicates and stored at $4{ }^{\circ} \mathrm{C}$ for one month. The butter samples were inoculated with the bacterial strains before packing. Thus, each butter sample was inoculated with $1 \mathrm{~mL}$ of suspension of $0.5 \mathrm{McF}$ arland $\left(1.5 \times 10^{8}\right)$ of each S. aureus and E. coli prepared from the working solution (Institute of Standard and Industrial Research of Iran, 2012b). After one month, the samples were kept under sterile conditions for 20 minutes at room temperature to soften slightly. The butter content of each package was poured into an Erlenmeyer and placed in a water bath to be melted at $35^{\circ} \mathrm{C}$. An amount $(90 \mathrm{~mL})$ of $40^{\circ} \mathrm{C}$-sterile peptone solution was added $10 \mathrm{~g}$ of melted butter, stirred and some samples were then removed from the aqueous phase for bacterial culture (Sarab et al., 2019). The 6-fold serial dilution was then prepared.

\subsection{Faecal coliform diagnosis and confirmation tests}

In order to detect coliforms (Bereda et al., 2018; Feng et al., 2002), $0.1 \mathrm{~mL}$ of the suspension (named final suspension) was removed from each of the last three diluted tubes $\left(10^{-4}, 10^{-5}\right.$, $10^{-6}$ ) and poured into a sterile plate pre-filled with $10 \mathrm{cc}$ of Violet Red Bile Agar (VRBA) medium, and two-layered culture was carried out through the pour plate method. The plates were then incubated at $37^{\circ} \mathrm{C}$ for $48 \mathrm{~h}$ and numerated for CFU based on the dilutions and $\mathrm{CFU}$ counted in the plate. A few purple colonies with bile halo grown in the VRBA medium were removed and aseptically transferred to sterile brilliant green bile (BGB) and lactose broth medium (Endol test). They were incubated at $37^{\circ} \mathrm{C}$ for $48 \mathrm{~h}$. After incubation, a red ring at the ambient surface appeared after adding a few drops of Kovacs' reagent to tubes containing the latter medium. An opaque colour then formed in BGB environment, along with the presence of gas in the Durham tubes, thus confirming the presence of coliforms in the samples. A loop of bacteria grown in the last positive tubes were removed, linear culture was performed on the Eosin Methylene-Blue Lactose Sucrose Agar (EMB, Sigma Aldrich, Germany) and incubated at $44.5^{\circ} \mathrm{C}$ for $24 \mathrm{~h}$ to confirm fecal coliform.

\subsection{Coagulase Staphylococcus test}

The $0.1 \mathrm{~mL}$ of the final suspension was removed, inoculated the surface of sterile plate pre-filled with $10 \mathrm{cc}$ Baird Parker agar (BPA Sigma Aldrich, Germany) and incubated at $37^{\circ} \mathrm{C}$ for $24 \mathrm{~h}$. The plates were counted with a glossy black colony with a thin white edge and clear halo (Sarab et al., 2019).

\subsection{Psychrophilic bacteria test}

The $0.1 \mathrm{~mL}$ of the final suspension was removed and added on to the surface of each sterile plate pre-filled with $10 \mathrm{cc}$ Plate 
Count Agar (PCA, Sigma Aldrich, Germany). They were then kept at refrigeration temperature $\left(6.5^{\circ} \mathrm{C}\right)$ for 10 days. White spindle-shaped colonies were counted (Sarab et al., 2019).

\section{Bacterial Total Count (TC)}

The $0.1 \mathrm{~mL}$ of the final dilution was inoculated on each plate containing $10 \mathrm{~mL}$ of plate count agar (Sigma Aldrich, Germany). After the agar was firmed, the plates were inoculated at $37^{\circ} \mathrm{C}$ for 36-48 h (Bereda et al., 2018).

\subsection{Moisture content}

A specific weight of butter was heated at $102{ }^{\circ} \mathrm{C} \pm 2{ }^{\circ} \mathrm{C}$. The dry matter was weighed as moisture content. The volume of percent moisture was calculate using Equation 1:

$\mathrm{Wm}=\frac{(\mathrm{ml}-\mathrm{m} 2)}{(\mathrm{ml}-\mathrm{m} 0)} \times 100$

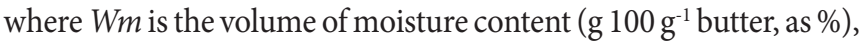
$\mathrm{m}_{0}$ is the weight $(\mathrm{g})$ of the bare beaker, $\mathrm{m}_{1}$ is the weight $(\mathrm{g})$ of beaker and butter contained therein before heating and $\mathrm{m}_{2}$ is the weight $(\mathrm{g})$ of beaker and butter contained therein after heating (Evers et al., 2003).

\subsection{Solid-non-fat (SNF) content}

The volume of percent SNF was calculated using Equation 2:

$\mathrm{Ws}=\frac{(\mathrm{m} 1-\mathrm{m} 0)}{(\mathrm{m} 2-\mathrm{m} 0)} \times 100$

where $W s$ is the volume of SNF content ( $100 \mathrm{~g}^{-1}$ butter, as \%), $\mathrm{m}_{0}$ is the weight $(\mathrm{g})$ of the bare beaker, $\mathrm{m}_{1}$ is the weight $(\mathrm{g})$ of the bare beaker along with dried SNF and $\mathrm{m}_{2}$ is the weight $(\mathrm{g})$ of the butter sample along with the beaker (Evers et al., 2003).

\subsection{Content of fat-by-difference}

The volume of percent Fat-by-difference was calculated using Equation 3:

$\mathrm{Wf}=100-(\mathrm{Wm}-\mathrm{Ws})$

where wf; wm and ws are the volume of fat ( $\mathrm{g} 100 \mathrm{~g}^{-1}$ butter, as \%), volume of moisture ( $\mathrm{g}_{100 \mathrm{~g}^{-1}}$ butter, as \%) and the the volume of SNF ( $\mathrm{g} 100 \mathrm{~g}^{-1}$ butter, as \%) respectively (Evers et al., 2003).

\subsection{Fatty acid composition}

Fatty acid (FA) content was measured using Gas Chromatography (GC). The $500 \mu \mathrm{L}$ hexane and $200 \mu \mathrm{L}$ of $2 \mathrm{~N} \mathrm{KOH}$ in methanol were macerated into the control and treatment tubes each containing $50 \mu \mathrm{L}$ of the butter to derivate it to fatty acid methyl esters (FAME). The combination was stirred up to $5 \mathrm{~min}$ and the upper organic phase that contained FAME was three times extracted for evaluation using a gas chromatography equipped with a flame ionization detector (Agilent $6890 \mathrm{~N}$ Hewlett-Packard
Co., Avondale, PA, USA) (FID) and a capillary column with dimensions of $100 \mathrm{~m} \times 0.25 \mathrm{~mm} \times 0.2 \mu \mathrm{m}$. Respectively, air flow and hydrogen levels were set to 300 and $30 \mathrm{~mL} \mathrm{~min}^{-1}$. Results were ultimately presented as w/w (\%) total FA (Bali et al., 2017).

\subsection{Peroxide test}

Peroxide value of the butter samples was measured following the method presented by (AOAC standard methods CD-8b-90) (21). The $30 \mathrm{~mL}$ combination of glacial acetic acid and chloroform $(3: 1 \mathrm{v} / \mathrm{v})$ solution was macerated into the Erlenmeyer flask containing $5 \mathrm{~g}$ of butter samples and slightly stirred, followed by adding $0.5 \mathrm{~mL}$ of the saturated potassium iodide. The solution was added with $30 \mathrm{~mL}$ of deionized water after it was left in darkness for a minute. The $0.01 \mathrm{~N}$ sodium thiosulphate solution was added to the combination to titrate until the yellow color disappeared. The next titration was carried out by adding $0.5 \mathrm{~mL}$ of the starch adhesive reagent $(1 \% \mathrm{w} / \mathrm{v})$ to the flasks, and constant shaking was continued until the blue color disappeared. The peroxide value $(\mathrm{mEq} / \mathrm{kg})$ was calculated according to the following Equation 4:

$\mathrm{p}=\frac{\mathrm{N}(\mathrm{S}-\mathrm{B})}{\mathrm{W}} \times 1000$

where $p$ is the peroxide number of butter sample (meq $/ \mathrm{kg}$ butter), $\mathrm{N}$ is normality of the thiosulphate solution, $\mathrm{S}$ is the volume of sodium thiosulphate used by fat of samples $(\mathrm{mL}), \mathrm{B}$ is the volume of sodium thiosulphate used by blank, and $\mathrm{W}$ is the sample was used $(\mathrm{g})$.

\subsection{Melting point test}

Melting point of the butter samples was measured according to (AOCS method Cc1-25) (24). Capillary tubes were filled with a $1 \mathrm{~cm}$ high column of melted butter. The capillary tubes were then placed in an ice-filled beaker for a few seconds until they were being chilled in a cold bath to solidify the butter for $5 \mathrm{~min}$. The tubes were then contacted to a thermometer, and placed in a beaker prefilled with distilled $15^{\circ} \mathrm{C}$-water. The bath temperature was set to $37^{\circ} \mathrm{C}$, and heat was applied to increase the temperature at a rate of $3-4{ }^{\circ} \mathrm{C} / \mathrm{min}$. As soon as the fat column rose in one of the two capillaries, the temperature was reported as melting point.

\subsection{Iodine index measurement}

The $10 \mathrm{cc}$ of chloroform and $25 \mathrm{cc}$ of Hanus reagent were macerated to $0.25 \mathrm{~g}$ of the butter sample (Issa et al., 2017). The mixture was left in the dark room for 30 minutes. Potassium iodide $15 \%$ was added and the solution was then titrated in the presence of starch adhesive with 0.1 normal thiosulfate (titration continued until white color appeared).

\subsection{Acidity measurement (oleic acid base)}

The $2 \mathrm{~g}$ of each butter sample was mixed with $30 \mathrm{cc}$ of alcohol using magnetic stirrer and a few drops of phenolphthalein reagent were trickled to titrate with a 0.1 normal $\mathrm{NaOH}$ until a light pink color appeared (1). 


\subsection{Measurement of saponification index}

The $2 \mathrm{~g}$ of each butter sample was transferred to Erlenmeyer flask containing $50 \mathrm{cc}$ of $\mathrm{KOH}$, placed in water bath using a reflex set for $30 \mathrm{~min}$ (Al-Bachir \& Othman, 2019). A few drops of phenolphthalein reagent were trickled to titrate with a 0.5 normal $\mathrm{HCl}$ until a yellow color appeared.

\subsection{Statistical analyses}

A mixed model-ANOVA Repeated Measurement within the General Linear Model (GLM) procedure of SPSS version 18 (SPSS Inc., IL, USA) was used to control which interaction could be significant for dependent variables in the artificially bacterial contaminated butters. When $p$-values were less than 0.05 , the difference between the individual estimated marginal mean was significant using an ANOVA specific model followed post-hoc Tukey's HSD test $(p<0.05)$. A Univariate analysis was followed while the former model would not be significant ( $p>0.05$ ).

\section{Results and discussion}

\subsection{SEM Test}

Particle-size distribution with $20 \mathrm{kV}$ and magnification of $200 \mathrm{kx}$ are shown in Figure 1. In the image examined with SEM, agglomeration was extremely low, and the homogeneity of the coating surface was evident. The Ag-NPs size of nanocomposite coatings was ranged from 15.97 to 25.86 , and the average particle size was $20.63 \mathrm{~nm}$ (Figure 1). To date, there are few studies have
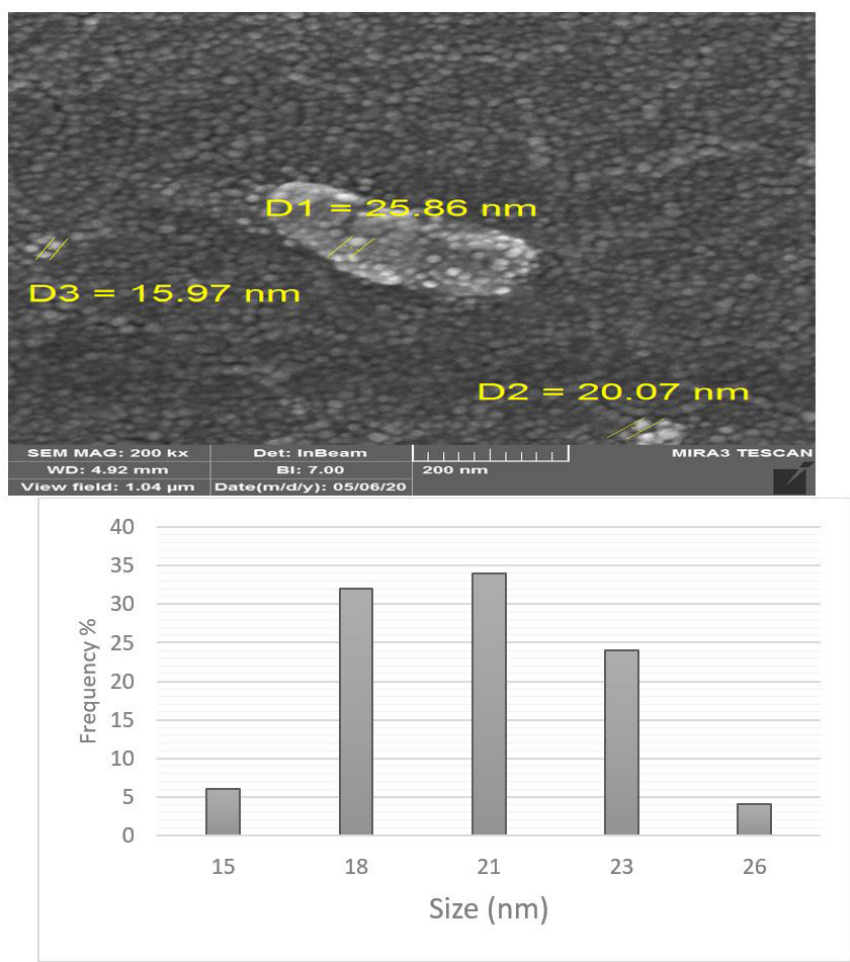

Figure 1. The scanning electron microscope (SEM) of $17.5 \%$ (Above $\times$ $200 \mathrm{kx}$ ) and frequency distribution (Below) showing the size of Ag-NC film. D: Diameter, D1: The largest diameter; D2: Medium Diameter; D3: The Smallest Diameter. investigated the association between nano/LDPE composites and shelf life of the butter. The size of nanoparticles of the packaging is a crucial factor for the production of nanocomposites. The average size of nanoparticles produced throughout the chemical reduction method (Figure 1) was $20.63 \mathrm{~nm}$, which is similar to those of other researchers have evidenced on NPs production size of $23.8 \mathrm{~nm}$ (Goharshadi \& Azizi-Toupkanloo, 2013), $21 \mathrm{~nm}$ (Van Dong et al., 2012), and the size of nanoparticles between 10 and 30 nanometers (Khan et al., 2011). Small nanoparticles containing 10-30 $\mathrm{nm}$ in diameter exhibited more antibacterial properties than larger nanoparticles (Jeong et al., 2014).

\subsection{Microbial tests}

Table 1 shows the microbial status obtained from the $\mathrm{Pa}$ and Tr butters wrapping in different Ag-LDPE nanocomposite (AgNC) films through the storage time. These data implied on the reduction of total bacteria count (TBC), S. aureus, E. coli, and psychrophilic bacteria with Ag-LDPE concentration-dependent manner so that the TBC of $\mathrm{Pa}$ butter was $14.66 \times 10^{4} \mathrm{CFU} / \mathrm{g}$ in the control group on the first day and gradually reached $7.33 \times 10^{4} \mathrm{CFU} / \mathrm{g}$ in the butter enfolded in $17.5 \% \mathrm{Ag}$-LDPE. It was remarkably decreased and reached "Not Determined" (ND) in the Pa butters enfolded with $12.5 \%$ and $17.5 \% \mathrm{Ag} / \mathrm{LDPE}$ films after 30 days of preservation. The TBC of Pa butters inoculated with $2 \%$ Origanum acutidens or $2 \%$ Thymus haussknechtii extracts reached $831.76 \times 10^{4}$ and $309.02 \times 10^{4} \mathrm{CFU} / \mathrm{g}$ after 30 days at $4^{\circ} \mathrm{C}$ (Dagdemir et al., 2009) more remarkable than those gained in this study and another research conducted on the effect of gamma irradiation at a dose of $2.5 \mathrm{kGy}$ exposing to $\mathrm{Pa}$ butter samples (Rady \& Badr, 2003), which showed that the TBC reached $66 \times 10^{4} \mathrm{CFU} / \mathrm{g}$ at refrigerating condition. The discussion as mentioned earlier confirmed that nanosilver coating at $12.5 \%$ and $17.5 \%$ had good effectiveness in reducing bacterial load in Pa butter during 30 days of cold storage.

On the other hands, TBC was decreased (83.33 and $16.00 \times 10^{4} \mathrm{CFU} / \mathrm{g}$ ) in Tr butter wrapped with $12.5 \%$ and $17.5 \%$ Ag/LDPE films after 30 days (Table 1) but significantly greater $(\mathrm{p}<0.05)$ than the standard level $\left(7.5 \times 10^{4} \mathrm{CFU} / \mathrm{g}\right)$. Unlike with TBCs of butter wrapped with $12.5 \%$ and $17.5 \% \mathrm{Ag}$-LDPE films, the values of other groups showed an increase from the first to thirtieth day in Tr butters. High TBC in Tr butter could be due to a high bacterial load of applied milk, lack of pasteurization and technology of heating, and the effect of both segregation and agitating procedures of butter production on the breakaway of bacterial mass result in increases their number (Gazu et al., 2018). Result of a research (Idoui et al., 2010) showed TBC of samples isolated from $\operatorname{Tr}$ cow butter ranged from $15 \times 10^{4}$ to $600 \times 10^{4} \mathrm{CFU} / \mathrm{g}$, which was relatively in agreement with this result showed $191 \times 10^{4} \mathrm{CFU} / \mathrm{g}$ at the first day more sumptuous than the samples were taken from Tr Tunisian butters, which it gone $7.00 \times 10^{4} \mathrm{CFU} / \mathrm{mL}$ at the same time (Samet-Bali et al., 2009). TBC in Pa butter was reached $2.49 \times 10^{3} \mathrm{CFU} / \mathrm{g}$ after four weeks of cold storage while green tea extract was inoculated to butter (Thakaeng et al., 2020), showing less value compared to this study (Table 1).

The result of $E$. coli and $S$. aureus count (SC) was ND before the study for both $\mathrm{Pa}$ and $\mathrm{Tr}$ butters (Not given in the 
Table 1. Estimates of bacterial count $\left(\times 10^{4} \mathrm{cfu} / \mathrm{g}\right)$ isolated from butters (Mean $\pm \mathrm{SE}$ ) covered with different concentration of Ag-nano composite films during the storage $(\mathrm{n}=3)$.

\begin{tabular}{|c|c|c|c|c|c|c|c|c|c|}
\hline \multirow{2}{*}{ Bacteria } & \multirow{2}{*}{$\mathrm{D}$} & \multirow{2}{*}{ But } & \multicolumn{5}{|c|}{ Ag-nanocomposite $\%$} & \multirow{2}{*}{ SE } & \multirow{2}{*}{$\begin{array}{l}\text { NS (Institute of Standarc } \\
\text { and Industrial Research } \\
\text { of Iran, 2012b) }\end{array}$} \\
\hline & & & 0 & 2.5 & 7.5 & 12.5 & 17.5 & & \\
\hline \multirow{4}{*}{ Total count ${ }^{* * *}$} & \multirow{2}{*}{1} & $\mathrm{P}$ & $14.66^{\mathrm{aA}}$ & $11.66^{\mathrm{bA}}$ & $8.66^{\mathrm{cA}}$ & $8.33^{c}$ & $7.33^{c}$ & 3.43 & \multirow{4}{*}{$<7.5 \times 10^{4}$} \\
\hline & & $\mathrm{T}$ & $191.00^{\mathrm{aA}}$ & $180.00^{\mathrm{bA}}$ & $127.66^{\mathrm{cA}}$ & $111.00^{\mathrm{dA}}$ & $86.66^{\mathrm{eA}}$ & 3.43 & \\
\hline & \multirow{2}{*}{30} & $\mathrm{P}$ & $229.66^{\mathrm{aB}}$ & $87.00^{\mathrm{bB}}$ & $35.00^{\mathrm{cB}}$ & ND & $\mathrm{ND}$ & 3.43 & \\
\hline & & $\mathrm{T}$ & $290.66^{\mathrm{aB}}$ & $260.66^{\mathrm{bB}}$ & $229.66^{\mathrm{cB}}$ & $83.33^{\mathrm{dB}}$ & $16.00^{\mathrm{eB}}$ & 3.43 & \\
\hline \multirow{4}{*}{ Staphylococcus $C+{ }^{* * *}$} & \multirow{2}{*}{1} & $\mathrm{P}$ & $19.33^{\mathrm{aA}}$ & $5.00^{\mathrm{bA}}$ & $5.00^{\mathrm{bA}}$ & $4.00^{\mathrm{bA}}$ & ND & 1.07 & \multirow{4}{*}{0} \\
\hline & & $\mathrm{T}$ & $9.00^{\mathrm{aA}}$ & $9.00^{\mathrm{aA}}$ & $1.33^{\mathrm{bA}}$ & $2.13^{\mathrm{bA}}$ & $2.66^{\mathrm{bA}}$ & 1.07 & \\
\hline & \multirow{2}{*}{30} & $\mathrm{P}$ & $20.66^{\mathrm{aA}}$ & $12.33^{\mathrm{bB}}$ & $4.66^{\mathrm{cA}}$ & $4.66^{\mathrm{cA}}$ & $\mathrm{ND}$ & 1.07 & \\
\hline & & $\mathrm{T}$ & $270.66^{\mathrm{aB}}$ & $175.66^{\mathrm{bB}}$ & $35.57^{\mathrm{cB}}$ & $69.33^{\mathrm{dB}}$ & $54.00^{\mathrm{eB}}$ & 1.07 & \\
\hline \multirow{4}{*}{ E. coli $* * *$} & \multirow{2}{*}{1} & $\mathrm{P}$ & $33.33^{\mathrm{aA}}$ & $31.00^{\mathrm{aA}}$ & $31.66^{\mathrm{aA}}$ & $6.33^{\mathrm{b}}$ & $4.75^{\mathrm{b}}$ & 0.64 & \multirow{4}{*}{0} \\
\hline & & $\mathrm{T}$ & $285.00^{\mathrm{aA}}$ & $280.00^{\mathrm{aA}}$ & $290.00^{\mathrm{aA}}$ & $290.00^{\mathrm{aA}}$ & $22.50^{\mathrm{bA}}$ & 0.64 & \\
\hline & \multirow{2}{*}{30} & $\mathrm{P}$ & $33.00^{\mathrm{aA}}$ & $31.00^{\mathrm{aA}}$ & $6.33^{\mathrm{bB}}$ & ND & ND & 0.64 & \\
\hline & & $\mathrm{T}$ & $38.33^{\mathrm{aB}}$ & $32.33^{\mathrm{bB}}$ & $32.00^{\mathrm{bB}}$ & $2.00^{\mathrm{cB}}$ & $1.33^{\mathrm{cB}}$ & 0.64 & \\
\hline \multirow{4}{*}{ Psychrophilic b. ${ }^{* * *}$} & \multirow{2}{*}{1} & $\mathrm{P}$ & $163.33^{\mathrm{A}}$ & ND & ND & ND & ND & 4.76 & \multirow{4}{*}{$10^{4}$} \\
\hline & & $\mathrm{T}$ & $203.33^{\mathrm{A}}$ & ND & ND & ND & ND & 4.76 & \\
\hline & \multirow{2}{*}{30} & $\mathrm{P}$ & $171.66^{\mathrm{B}}$ & ND & $\mathrm{ND}$ & ND & $\mathrm{ND}$ & 4.76 & \\
\hline & & $\mathrm{T}$ & $290.66^{\mathrm{aB}}$ & $266.00^{\mathrm{b}}$ & $260.33^{\mathrm{b}}$ & $110.33^{\mathrm{c}}$ & $79.00^{\mathrm{d}}$ & 4.76 & \\
\hline
\end{tabular}

But: Butter, D: Days; C+: Coagulase-positive; P: Pasteurized; T: Traditional; ND: Not determined; NS: National standard; SE: standard error. Different small superscripts in each row indicate a significant difference $(\mathrm{P}<0.05)$. Capital superscripts in each column (for comparing between the values of same butter type and day) indicate a significant difference at a $\mathrm{p}$ value of 0.05 . For interaction of dependent variables ${ }^{*} \mathrm{p}<0.05,{ }^{* *} \mathrm{p}<0.01$ and ${ }^{* * *} \mathrm{p}<0.001$

Tables). Once inoculation of $S$. aureus to butter was done, the SC reached $19.33 \times 10^{4} \mathrm{CFU} / \mathrm{g}$ in Pa butters (Table 1 ) of the control group on 1 st day, gradually decreased $(\mathrm{p}<0.05)$ in butters with different concentrations of Ag-LDPE and reached the least values $\left(4.00 \times 10^{4} \mathrm{CFU} / \mathrm{g}\right.$ and $\left.\mathrm{ND}\right)$, respectively in $12.5 \%$ and $17.5 \%$ Ag-LDPE films. Similarly, this value declined and reached $4.66 \times 10^{4} \mathrm{CFU} / \mathrm{g}$ and ND isolated from samples of $12.5 \%$ and 17.5\% Ag-NCAg-LDPE films after 30 days. The SC for Tr samples started from $9.00 \times 10^{4} \mathrm{CFU} / \mathrm{g}$ in the control group and ended at $2.66 \times 10^{4} \mathrm{CFU} / \mathrm{g}(\mathrm{p}<0.05)$ in $17.5 \% \mathrm{Ag}$-LDPE film samples. The SC was increased more than twenty-thirtyfold after a month of cold preservation in Tr butters wrapped with different concentrations of Ag/LDPE films. This result indicated that only the $17.5 \% \mathrm{Ag} / \mathrm{LDPE}$ film could eliminate $S$. aureus from Pa butter samples. The results (Table 1) showed less capability of Ag-LDPE on reducing S. aureus value in $\mathrm{Tr}$ butter in comparison with $\mathrm{Pa}$ butter. Thus, this value for Tr butters decreased from 270.66 $\times 10^{4} \mathrm{CFU} / \mathrm{g}$ on the 1 st day to $54.00 \times 10^{4} \mathrm{CFU} / \mathrm{g}$ after 30 days of the cold preservation. The value of $S$. aureus isolated from $\mathrm{Tr}$ butter was about $1 \times 10^{4}-10^{6} \mathrm{CFU} / \mathrm{g}$ (Mehdizadeh et al., 2019; Rahimi, 2013) which could be diminished by $2.8 \log$ CFU/g after inoculation with $0.5 \%$ WHE (walnut kernel septum membranes hydroalcoholic extract) reached $1.3 \times 10^{4} \mathrm{CFU} / \mathrm{g}$ after 45 days (Mehdizadeh et al., 2019). Contrarily, Sarab et al. (2019) showed coagulase-positive $S$. aureus isolated from Tr cow butters was reached $0.12 \mathrm{CFU} / \mathrm{g}$ without initial bacterial inoculation. Accordingly, 17.5\% Ag-LDPE film could eliminate $S$. aureus in $\mathrm{Pa}$ butter at the end of storage vs. Tr samples of which the Ag-LDPE films could not effectively eliminate $S$. aureus. Our result demonstrated that the value of $S$. aureus was gradually diminished after inoculation, from $20.66 \times 10^{4} \pm 1.07 \mathrm{CFU} / \mathrm{g}$ (0\% Ag-LDPE) to ND (17.5\% Ag-LDPE) in Pa butter on day
30 indicating the increase effectiveness of Ag-LDPE film on reducing $S$. aureus in a dose-dependent manner.

The value of $E$. coli in $\mathrm{Pa}$ butter was $33.33 \times 10^{4} \mathrm{CFU} / \mathrm{g}$ in the control group on the first day with no significant difference ( $p>0.05$ ) compared to that of the same group on day 30. This value for Pa butters covered with 7.5\%, $12.5 \%$ and $17.5 \%$ Ag-LDPE were decreased on day $30\left(6.33 \times 10^{4} \mathrm{CFU} / \mathrm{g}\right.$, ND and ND, respectively) while the values for $\mathrm{Tr}$ butters were $32.00,2.00$, and $1.00 \times 10^{4} \mathrm{CFU} / \mathrm{g}$, respectively. on 30 th day $\left(38.33 \times 10^{4} \mathrm{CFU} / \mathrm{g}\right)$, which later showed no significant difference ( $\mathrm{p}>0.5$ ) with those of $2.5 \% \mathrm{Ag}$-LDPE $\left(32.33 \times 10^{4} \mathrm{CFU} / \mathrm{g}\right)$ and $7.5 \% \mathrm{Ag}$-LDPE $\left(32.00 \times 10^{4} \mathrm{CFU} / \mathrm{g}\right)$ and significantly decreased $(\mathrm{p}<0.05)$ at $12.5 \%$ and $17.5 \% \mathrm{Ag}$-LDPE butters $\left(2.00 \times 10^{4} \mathrm{CFU} / \mathrm{g}\right.$ and $1.33 \times 10^{4} \mathrm{CFU} / \mathrm{g}$, respectively) but did not reach ND. Notwithstanding the value of inoculation to the butters, the Pa butter covered with $12.5 \%$ and $17.5 \%$ Ag-LDPE films could eliminate E. coli from the butter. This result (Table 1) indicated that the efficiencies of Ag-LDPE films on diminishing E. coli from the Pa butters were more superior to that of the Tr ones. Active cellulose-based papers loaded in chitosan- $\mathrm{Ag} / \mathrm{TiO} 2$ was suggested (Apjok et al., 2019) to be effective to reduce E. coli (2 CFU/g) from clarified butter relatively similar to this result showed not only $12.5 \%$ and $17.5 \%$ Ag-LDPE films to fully diminish E. coli in Pa butter after 30 days (ND) but also they decreased E. coli in Tr butters by 4.5 and $4.12 \log \mathrm{CFU} / \mathrm{g}$, respectively. A dose of $2.5 \mathrm{kGy}$ gamma irradiation exposed to Pa butter samples could not inhibit the growth of coliforms, so that it was measured 120.0 CFU/g on the 1st day and reached $730.0 \mathrm{CFU} / \mathrm{g}$ on day 30 against $5 \mathrm{kGy}$ gamma irradiation showed no coliforms could grow (ND) in the Pa butter (Rady \& Badr, 2003) similar to the results of adding 0.5\% WHE (Mehdizadeh et al., 2019) and $12.5 \%$ 
and $17.5 \%$ Ag-LDPE films of this study (Table 1) showing E. coli were completely diminished in the Pa butters.

The result of psychrophilic bacteria was listed in Table 1. It showed that the bacteria would be sensitive while the Pa butter wrapped in the different concentrations of Ag-LDPE films even after 30 days so that its value showed no bacteria (ND) in the $\mathrm{Pa}$ butter samples enfolded different concentrations of Ag/LDPE film. The psychrophilic bacteria showed proper growth in the Tr butter samples wrapped even with $17.5 \%$ Ag-LDPE films $\left(79.00 \times 10^{4} \mathrm{CFU} / \mathrm{g}\right)$. This result (Table 1) exhibited that Ag/LDPE film at different concentrations was effectively eliminated psychrophilic bacteria in Pa butters preserved in refrigerated temperature after 30 days while it showed no efficiency against $\operatorname{Tr}$ bacteria in the same condition. On the other hand, the $0.5 \% \mathrm{WHE}$ could not effectively remove psychrophilic bacteria from the $\mathrm{Pa}$ butter so that its value reached $5.07 \log \mathrm{CFU} / \mathrm{g}$ after 45 days of the storage (Mehdizadeh et al., 2019). Dairy product shelf life was intensified by low oxygen atmospheres due to depletion in the spoilage microorganisms including aerobic Gram-negative psychrotrophic bacteria, particularly Pseudomonas spp (Singh et al., 2012). Accordingly, the most antibacterial effect of an adequate dose of $\mathrm{Ag}^{+}$is notably observed in Gram-negative bacteria demonstrating that $\mathrm{Ag}^{+}$directly interacts with and disrupts Fe-S clusters in the outer membrane (Morones-Ramirez et al., 2013), results in low values of E. coli (Table 1).

\subsection{Physicochemical tests}

Table 2 displays the physicochemical properties of the commercial preparation of $\operatorname{Tr}$ and Pa butters. Out of the independent variables mentioned in Table 2, the interaction of time and Ag-LDPE film showed the maximum effectiveness on moisture, SNF, and Fat $(\mathrm{p}<0.05 ; \eta \mathrm{p} 2=0.30, \eta \mathrm{p} 2=0.985$, $\eta \mathrm{p} 2=0.985$; respectively). Initially, the moisture value (\%) of Tr Butter of the control group as well as the treatments, was significantly $(\mathrm{p}<0.05)$ more generous than those of $\mathrm{Pa}$ one in the same group. On the other hand, the data (Table 2) indicated that moisture value (\%) of the butters (Pa or $\mathrm{Tr}$ ) with different Ag-LDPE films on day 30 had no significant difference $(p>0.05)$ compared to that of the initial day. The moisture of $\mathrm{Pa}$ and $\mathrm{Tr}$ butters covered with $17.5 \% \mathrm{Ag}$-LDPE was $14.22 \%$ and $15.69 \%$, which had no significant difference ( $p>0.05)$ with those of other concentrations Ag-LDPE films. The minimum and maximum moisture values were $14.78 \%$ and $14.50 \%$, respectively for control and $17.5 \%$ Ag-LDPE film on day 30.

Similar to our results, the moisture value of butter approximately was $15.00 \%$ (Mehdizadeh et al., 2019), which was less than the standard (Institute of Standard and Industrial Research of Iran, 2012a). In addition to fats, butter encompasses low portions of proteins and moisture making it a proper environment for microbial growth (Rady \& Badr, 2003). The LDPE is a polymer that is widely used in food packaging. The advantages of this polymer are permeability to oxygen and very low impermeability to water and moisture (Dirim et al., 2004), which could be an apparent response to the inalterability of moisture in $\mathrm{Pa}$ and $\mathrm{Tr}$ butters after 30d. Regardless of butter type, the water content of the butters showed no significant difference $(p>0.05)$ within the treatments ranging from $14.94 \%$ to $14.98 \%$ on the beginning of the study and 14.50 to 14.78 after 30 days of the study. Development of bacterial spoilage is a rancidity process of butter complications, which can be produced through hydrolysis. Many psychrophilic bacteria, such as $S$. aureus, have been involved in lipolysis at low temperature of preserved butter (Rady \& Badr, 2003). Butter with $80-82 \%$ lipid element is a palatable lipid percentage throughout the world (Mofid et al., 2018), which is in agreement with this result (Table 2) showed the fat content is approximately ranging $82.81-84.35 \%$.

The SNF value (\%) of the butters had no any significant changes $(p>0.05)$ after 30 days of the cold storage (Table 2) so that the SNF value of $\mathrm{Pa}$ and $\mathrm{Tr}$ butters on the 1st day was ranging $1.22-1.25 \%$ and $1.53-1.58 \%$, respectively with no significant difference $(\mathrm{p}>0.05)$ compared to those of 30 th day. These results showed that Tr butter had insignificantly ( $p>0.05)$ more SNF than Pa one. The SNF (\%) of Tr samples was greater than that of Pa butter (Table 2). It could be due to the process of traditional butter production, in which butter extraction is prepared from the yoghurt results in infiltration of phosphorus,

Table 2. Gross composition (w/w (\%) of butters (Mean \pm SE) at different concentration of Ag-nano composite films during the storage.

\begin{tabular}{|c|c|c|c|c|c|c|c|c|c|}
\hline \multirow{2}{*}{ Bacteria } & \multirow{2}{*}{$\mathrm{D}$} & \multirow{2}{*}{ But } & \multicolumn{5}{|c|}{ Ag-nanocomposite $\%$} & \multirow{2}{*}{ SE } & \multirow{2}{*}{ NS } \\
\hline & & & 0 & 2.5 & 7.5 & 12.5 & 17.5 & & \\
\hline \multirow{4}{*}{ Moisture (\%) } & \multirow{2}{*}{1} & $\mathrm{P}$ & $14.23^{\mathrm{aA}}$ & $14.22^{\mathrm{aA}}$ & $14.24^{\mathrm{aA}}$ & $14.23^{\mathrm{aA}}$ & $14.22^{\mathrm{aA}}$ & 0.02 & \multirow{4}{*}{$<16 \%$} \\
\hline & & $\mathrm{T}$ & $15.71^{\mathrm{aB}}$ & $15.66^{\mathrm{aB}}$ & $15.70^{\mathrm{aB}}$ & $15.73^{\mathrm{aB}}$ & $15.69^{\mathrm{aB}}$ & 0.02 & \\
\hline & \multirow{2}{*}{30} & $\mathrm{P}$ & $14.05^{\mathrm{aA}}$ & $13.98^{\mathrm{aA}}$ & $13.88^{\mathrm{aA}}$ & $13.80^{\mathrm{aA}}$ & $13.73^{\mathrm{aA}}$ & 0.02 & \\
\hline & & $\mathrm{T}$ & $15.53^{\mathrm{aB}}$ & $15.45^{\mathrm{aB}}$ & $15.38^{\mathrm{aB}}$ & $15.32^{\mathrm{aB}}$ & $15.26^{\mathrm{aB}}$ & 0.02 & \\
\hline \multirow{4}{*}{ SNF (\%) } & \multirow{2}{*}{1} & $\mathrm{P}$ & $1.25^{\mathrm{aA}}$ & $1.23^{\mathrm{aA}}$ & $1.25^{\mathrm{aA}}$ & $1.22^{\mathrm{aA}}$ & $1.22^{\mathrm{aA}}$ & 0.01 & \multirow{4}{*}{$<2 \%$} \\
\hline & & $\mathrm{T}$ & $1.57^{\mathrm{aA}}$ & $1.58^{\mathrm{aA}}$ & $1.53^{\mathrm{aA}}$ & $1.58^{\mathrm{aA}}$ & $1.58^{\mathrm{aA}}$ & 0.01 & \\
\hline & \multirow{2}{*}{30} & $\mathrm{P}$ & $1.29^{\mathrm{aA}}$ & $1.25^{\mathrm{aA}}$ & $1.24^{\mathrm{aA}}$ & $1.24^{\mathrm{aA}}$ & $1.28^{\mathrm{aA}}$ & 0.01 & \\
\hline & & $\mathrm{T}$ & $1.66^{\mathrm{aA}}$ & $1.66^{\mathrm{aA}}$ & $1.66^{\mathrm{aA}}$ & $1.66^{\mathrm{aA}}$ & $1.65^{\mathrm{aA}}$ & 0.01 & \\
\hline \multirow{4}{*}{ Fat (\%) } & \multirow{2}{*}{1} & $\mathrm{P}$ & $84.39^{\mathrm{aA}}$ & $84.29^{\mathrm{aA}}$ & $84.40^{\mathrm{aA}}$ & $84.35^{\mathrm{aA}}$ & $84.33^{\mathrm{aA}}$ & 0.01 & \multirow{4}{*}{$>82 \%$} \\
\hline & & $\mathrm{T}$ & $82.87^{\mathrm{aB}}$ & $82.76^{\mathrm{aB}}$ & $82.79^{\mathrm{aB}}$ & $82.80^{\mathrm{aB}}$ & $82.80^{\mathrm{aB}}$ & 0.01 & \\
\hline & \multirow{2}{*}{30} & $\mathrm{P}$ & $84.37^{\mathrm{aA}}$ & $84.29^{\mathrm{aA}}$ & $84.30^{\text {aA }}$ & $84.33^{\mathrm{aA}}$ & $84.31^{\mathrm{aA}}$ & 0.01 & \\
\hline & & $\mathrm{T}$ & $84.37^{\mathrm{aA}}$ & $84.29^{\mathrm{aA}}$ & $84.30^{\mathrm{aA}}$ & $84.33^{\mathrm{aA}}$ & $84.32^{\mathrm{aA}}$ & 0.01 & \\
\hline
\end{tabular}

But: Butter, D: Days; SE: standard error; NS: National standard; SNF: solid-non-fat; P: Pasteurized; T: Traditional; Different small superscripts in each row indicate a significant difference at a $\mathrm{p}$ value of 0.05 . Capital superscripts in each column (for comparing between the values of same butter type) indicate a significant difference at a $\mathrm{p}$ value of 0.05 . For interaction of dependent variables ${ }^{*} \mathrm{p}<0.05,{ }^{* *} \mathrm{p}<0.01$ and ${ }^{* * *} \mathrm{p}<0.001$. 
calcium, and protein to ultimate butter (Mehdizadeh et al., 2019). According to Table 2, the SNF values for both butters were less than the standard (Institute of Standard and Industrial Research of Iran, 2012a). According to EU Council Regulation No. 2991/94, butters should enclose at least $80 \%$ fat, less than $16 \%$ water and 2\% SNF (European Union, 1994). The value of SNF of traditional cow butter was $1.90 \%$ relatively more than those of the Tr samples of this study (1.57).

On the first day, the fat content (\%) of the $\mathrm{Pa}$ and $\mathrm{Tr}$ butters (84.39\% and $82.87 \%$, respectively) of the control showed no significant difference $(\mathrm{p}>0.05)$ compared to corresponding butters wrapped with different concentrations of Ag/LDPE films. Its value of $\mathrm{Pa}$ butters showed no significant difference $(p>0.05)$ in different concentrations of Ag/LDPE after 30 days of cold storage. Still, it was increased (84.37\%) in Tr butters of control with no significant difference $(p>0.05)$ in comparison to the treatments at the same time (Table 2). Fat and SNF values of Irish summer butter were $82.15 \%$ and $1.96 \%$, respectively (Cronin et al., 2007).

Fatty acid compositions of the butter samples are presented in Table 3. According to ANOVA repeated measure test, the impact of different concentrations of Ag/LDPE films had no significant effect $(p>0.05)$ on the FFA content of both butters. However, lipid content showed that levels of the short-chain FAs (C4:0-C12:1) were lower in Pa butter (13.65\%, w/w) than that of $\operatorname{Tr}$ butter $(16.58 \%, \mathrm{w} / \mathrm{w})$. Accordingly, saturated FAs were calculated $70.15 \%(\mathrm{w} / \mathrm{w})$ and $72.79 \%(\mathrm{w} / \mathrm{w})$, respectively for $\mathrm{Pa}$ and $\mathrm{Tr}$ butters in the initial day. They reached $68.65 \%(\mathrm{w} / \mathrm{w})$ and $73.06 \%(\mathrm{w} / \mathrm{w})$, respectively after 30 days of cold storage. Monounsaturated FAs (MUFA) of Pa butter $(26.46 \%$, w/w) was remarkably more significant than that of $\mathrm{Tr}$ butter, approximately was $22.31 \%$, w/w. The higher proportion of FA was observed for palmitic acid, C:16 (33.94\%, 34.82\% w/w,) followed by oleic acid, C:18.1 (23.53\%, 18.44\%, w/w) and stearic acid, C:18 (11.50\%, $12.27 \%, w / w)$, respectively in $\mathrm{Pa}$ and $\operatorname{Tr}$ (Table 3). Regardless the concentration of Ag-LDPE film, the values of FA content of both Tr and Pa butters did not change during the storage exception for Linoleic acid, which is an essential polyunsaturated omega- $6 \mathrm{FA}$ for humans. The value of C18:2 FA of both $\mathrm{Pa}$ and $\mathrm{Tr}$ butters on the 30th day ( $4.90 \pm 0.02,4.63 \pm 0.02$, respectively) showed an increase compared with the initial day $(3.40 \pm 0.02,4.90 \pm 0.02$, respectively). Dislike, FFA content increased within the study days sampled from butters affected by extracts of sage, rosemary, and oregano (Ayar et al., 2001). In our study, Palmitic acid content of $\mathrm{Pa}$ and $\mathrm{Tr}$ butters respectively, were $33.9 \%$ and $34.8 \%$ greater than that of butter of cows fed on flaxseed (25.8\%) with no changes that occurred after one month of storage (Silva-Kazama et al., 2010). On the other hand, the value of stearic acid, which it is a waxy saturated fatty acid, was decreased after 45 days from $16.88 \%$ to $16.34 \%$ (Silva-Kazama et al., 2010) in comparison with this study represented $11.50 \%$ and $12.27 \%$ after 30 days with no remarkable changes against the initial day.

The results obtained from the preliminary analysis of physicochemical criteria can be observed in Table 4. Initially, PV of the Pa butter $(0.56 \mathrm{meq} / \mathrm{kg})$ was significantly greater $(\mathrm{p}<0.05)$ than those of Tr butter samples $(0.30 \mathrm{meq} / \mathrm{kg})$. These values showed no changes $(\mathrm{p}>0.05)$ by increasing the percent of
Table 3. Fatty acid compositions (w/w (\%)) of butters (Mean \pm SE) at different concentrations of Ag-nano composite films during the storage.

\begin{tabular}{|c|c|c|c|c|}
\hline FFA & Day & Butter & SE & NS \\
\hline \multirow{2}{*}{$\mathrm{C} 4$} & \multirow{2}{*}{ NA } & P $4.48^{\mathrm{a}}$ & 0.05 & \multirow{2}{*}{$1-5$} \\
\hline & & T $5.58^{\mathrm{b}}$ & 0.05 & \\
\hline \multirow{2}{*}{ C6 } & \multirow{2}{*}{ NA } & P 2.47 & 0.05 & \multirow{2}{*}{$0.8-3.6$} \\
\hline & & T $2.61^{\mathrm{a}}$ & 0.05 & \\
\hline \multirow{2}{*}{$\mathrm{C} 8$} & \multirow{2}{*}{ NA } & P $1.45^{\mathrm{a}}$ & 0.03 & \multirow{2}{*}{$0.5-1.8$} \\
\hline & & $\mathrm{T} 1.78^{\mathrm{a}}$ & 0.03 & \\
\hline \multirow{2}{*}{$\mathrm{C} 10$} & \multirow{2}{*}{ NA } & P $2.11^{\mathrm{a}}$ & 0.03 & \multirow{2}{*}{$1.7-3.9$} \\
\hline & & T $2.80^{\mathrm{a}}$ & 0.03 & \\
\hline \multirow{2}{*}{$\mathrm{C} 12$} & \multirow{2}{*}{ NA } & P $3.14^{\mathrm{a}}$ & 0.05 & \multirow{2}{*}{$2.2-4.5$} \\
\hline & & T $3.81^{\mathrm{a}}$ & 0.05 & \\
\hline \multirow{2}{*}{$\mathrm{C} 14$} & \multirow{2}{*}{ NA } & P $8.42^{\mathrm{a}}$ & 0.03 & \multirow{2}{*}{ 5.4-14 } \\
\hline & & $\mathrm{T} 9.51^{\mathrm{b}}$ & 0.03 & \\
\hline \multirow{2}{*}{ C14:1 } & \multirow{2}{*}{$\mathrm{NA}$} & P $1.69^{a}$ & 0.04 & \multirow{2}{*}{$0.5-1.8$} \\
\hline & & T $1.80^{\mathrm{a}}$ & 0.04 & \\
\hline \multirow{2}{*}{$\mathrm{C} 16$} & \multirow{2}{*}{ NA } & P33.94 & 0.07 & \multirow{2}{*}{$22-41$} \\
\hline & & T34.82 & 0.07 & \\
\hline \multirow{2}{*}{ C16:1 } & \multirow{2}{*}{ NA } & P $1.23^{\mathrm{a}}$ & 0.02 & \multirow{2}{*}{$0.7-6$} \\
\hline & & T $2.07^{\mathrm{a}}$ & 0.02 & \\
\hline \multirow{4}{*}{$\mathrm{C} 18$} & \multirow{2}{*}{1} & $\mathrm{P} 11.50^{\mathrm{aA}}$ & 0.02 & \multirow{4}{*}{ 6-15 } \\
\hline & & $\mathrm{T} 11.50^{\mathrm{aA}}$ & 0.03 & \\
\hline & \multirow{2}{*}{30} & $\mathrm{P} 11.50^{\mathrm{aA}}$ & 0.02 & \\
\hline & & $\mathrm{T} 12.27^{\mathrm{aB}}$ & 0.03 & \\
\hline C $18 \cdot 1$ & & P $23.53^{\mathrm{a}}$ & 0.03 & $18-38$ \\
\hline & & T $18.44^{\mathrm{b}}$ & 0.03 & $18-38$ \\
\hline & 1 & P $3.40^{\mathrm{aA}}$ & 0.02 & \\
\hline$C 10.2$ & 1 & $\mathrm{~T} 4.90^{\mathrm{bA}}$ & 0.03 & 0755 \\
\hline C18:2 & 30 & P $4.90^{\mathrm{aB}}$ & 0.02 & $0.7-5.5$ \\
\hline & 30 & $\mathrm{~T} 4.63^{\mathrm{aB}}$ & 0.03 & \\
\hline C20 & NA & P $0.04^{\mathrm{a}}$ & 0.02 & 0.4 \\
\hline $\mathrm{C} 20$ & NA & $\mathrm{T} 0.80^{\mathrm{b}}$ & 0.03 & $0.05-1$ \\
\hline
\end{tabular}

NS: National standard; P: Pasteurized; T: Traditional; N.A.: Not affected associated with dependent variable (s); SE: standard error. Different small superscripts in a raw for C16 (for other FFA: Free Fatty Acid compares between the values at same day in a column) indicate a significant difference at a p value of 0.05 . Capital superscripts in each column (for comparing between the values of same butter type) indicate a significant difference at a $p$ value of 0.05 . For interaction of dependent variables ${ }^{*} p<0.05$, ${ }^{* *} p<0.01$ and ${ }^{* * *} \mathrm{p}<0.001$.

$\mathrm{Ag} / \mathrm{LDPE}$ film. It was lower than the national standard for butter, which should be less than $1.0 \mathrm{meq} / \mathrm{kg}$ (Institute of Standard and Industrial Research of Iran, 2012a). Accordingly, the trend of the PV showed a slight fall from 0.50 and $0.28 \mathrm{meq} / \mathrm{kg}$, respectively for $\mathrm{Pa}$ and $\mathrm{Tr}$ butters on the 30th day in the control group to 0.31 and $0.24 \mathrm{meq} / \mathrm{kg}$, respectively in the $17.5 \% \mathrm{Ag}$-LDPE film at the end of the storage with no significant difference $(p>0.05)$ with other treatments. Off-flavors coincide with an increase of oxidation levels, which indicates higher PV (Krause et al., 2008). This value is considered to be one of the most indicators to show the steps of oxidative rancidity of lipids. Other researchers (3) confirmed that tomato processing by-product extract at $800 \mathrm{mg} / \mathrm{kg}$ showed more efficiency ( $1.31 \mathrm{meq} / \mathrm{kg}$ ) to decrease PV in Tr Tunisian butter than $200 \mathrm{mg} / \mathrm{kg}$ butylated hydroxytoluene, BHT ( $4.38 \mathrm{meq} / \mathrm{kg}$ ) at cold storage. The uses of bagasse adsorbent reduced PV up to $26.67 \%$ in frying oil (Kaltsum et al., 2016). Green tea extract could decrease PV of Pa butter reached $0.59 \mathrm{meq} / \mathrm{kg}$ after $28 \mathrm{~d}$ 
Table 4. Estimates of physicochemical properties of butters (Mean \pm SE) covered with different concentration of Ag-nano composite films during the storage.

\begin{tabular}{|c|c|c|c|c|c|c|c|c|c|}
\hline \multirow{2}{*}{ Property } & \multirow{2}{*}{$\mathrm{D}$} & \multirow{2}{*}{$\mathrm{B}$} & \multicolumn{5}{|c|}{ Ag-nanocomposite\% } & \multirow{2}{*}{ SE } & \multirow{2}{*}{ NS } \\
\hline & & & 0 & 2.5 & 7.5 & 12.5 & 17.5 & & \\
\hline \multirow{4}{*}{ Peroxide (meq/kg) } & \multirow{2}{*}{1} & $\mathrm{P}$ & $0.56^{\mathrm{aA}}$ & $0.58^{\mathrm{aA}}$ & $0.57^{\mathrm{aA}}$ & $0.58^{\mathrm{aA}}$ & $0.59^{\mathrm{aA}}$ & 0.66 & \multirow{4}{*}{$<1$} \\
\hline & & $\mathrm{T}$ & $0.30^{\mathrm{aB}}$ & $0.28^{\mathrm{aB}}$ & $0.29^{\mathrm{aB}}$ & $0.26^{\mathrm{aB}}$ & $0.24^{\mathrm{aB}}$ & 0.66 & \\
\hline & \multirow{2}{*}{30} & $\mathrm{P}$ & $0.50^{\mathrm{aA}}$ & $0.49^{\mathrm{aA}}$ & $0.41^{\text {aA }}$ & $0.31^{\mathrm{bB}}$ & $0.31^{\mathrm{bB}}$ & 0.66 & \\
\hline & & $\mathrm{T}$ & $0.28^{\mathrm{aB}}$ & $0.26^{\mathrm{aB}}$ & $0.28^{\mathrm{aB}}$ & $0.24^{\mathrm{aB}}$ & $0.24^{\mathrm{aB}}$ & 0.66 & \\
\hline \multirow{2}{*}{ Melting point $\left({ }^{\circ} \mathrm{C}\right)$} & 1 & $\mathrm{P}$ & $30.67^{\mathrm{aA}}$ & $30.66^{\mathrm{a}}$ & $30.33^{\mathrm{aA}}$ & $29.00^{\mathrm{aA}}$ & $30.00^{\mathrm{aA}}$ & 0.66 & \multirow{2}{*}{$28-34$} \\
\hline & 30 & $\mathrm{~T}$ & $33.00^{\mathrm{aB}}$ & $32.00^{\mathrm{a}}$ & $32.66^{\mathrm{aB}}$ & $32.66^{\mathrm{aB}}$ & $32.00^{\mathrm{aB}}$ & 0.66 & \\
\hline \multirow{4}{*}{ Iodine $\left(I_{2} g / 100 g\right)$} & \multirow{2}{*}{1} & $\mathrm{P}$ & $31.29^{\mathrm{a}}$ & $31.85^{\mathrm{a}}$ & $32.16^{\mathrm{aA}}$ & $30.95^{\mathrm{a}}$ & $30.32^{\mathrm{aA}}$ & 1.51 & \multirow{4}{*}{$26-40$} \\
\hline & & $\mathrm{T}$ & $29.56^{\mathrm{a}}$ & $29.49^{\mathrm{a}}$ & $29.53^{\text {aA }}$ & $28.91^{\mathrm{a}}$ & $28.92^{\mathrm{aA}}$ & 1.51 & \\
\hline & \multirow{2}{*}{30} & $\mathrm{P}$ & $30.72^{\mathrm{a}}$ & $31.34^{\mathrm{a}}$ & $31.00^{\mathrm{aA}}$ & $31.12^{\mathrm{a}}$ & $30.46^{\mathrm{aA}}$ & 1.51 & \\
\hline & & $\mathrm{T}$ & $28.52^{\mathrm{a}}$ & $28.04^{\mathrm{a}}$ & $27.83^{\mathrm{aB}}$ & $28.62^{\mathrm{a}}$ & $25.26^{\mathrm{bB}}$ & 1.51 & \\
\hline \multirow{4}{*}{$\begin{array}{l}\text { Saponification } \\
(\mathrm{mg} \mathrm{KOH} / \mathrm{g})\end{array}$} & \multirow{2}{*}{1} & $P$ & $236.61^{\mathrm{aA}}$ & $234.70^{\mathrm{bA}}$ & $234.44^{\mathrm{bA}}$ & $234.69^{\mathrm{bA}}$ & $234.55^{\mathrm{bA}}$ & 1.29 & \multirow{4}{*}{$225-235$} \\
\hline & & $\mathrm{T}$ & $234.55^{\mathrm{aA}}$ & $234.15^{\mathrm{aA}}$ & $233.06^{\mathrm{aA}}$ & $234.32^{\mathrm{aA}}$ & $234.22^{\mathrm{aA}}$ & 1.29 & \\
\hline & \multirow{2}{*}{30} & $\mathrm{P}$ & $236.25^{\mathrm{aA}}$ & $231.45^{\mathrm{bA}}$ & $230.81^{\mathrm{bA}}$ & $229.65^{\mathrm{bA}}$ & $228.26^{\mathrm{bA}}$ & 1.29 & \\
\hline & & $\mathrm{T}$ & $233.47^{\mathrm{aA}}$ & $234.07^{\mathrm{aA}}$ & $232.28^{\mathrm{aA}}$ & $233.60^{\mathrm{aA}}$ & $233.88^{\mathrm{aA}}$ & 1.29 & \\
\hline
\end{tabular}

B: Butter, D: Days SE: standard error; NS: National Standard; P: Pasteurized; T: Traditional. Different small superscripts in each row indicate a significant difference at a p value of 0.05. Capital superscripts in each column (for comparing between the values of same butter type) indicate a significant difference at a $\mathrm{p}$ value of 0.05 . For interaction of dependent variables ${ }^{*} \mathrm{p}<0.05,{ }^{* *} \mathrm{p}<0.01$ and ${ }^{* * *} \mathrm{p}<0.001$.

at $4{ }^{\circ} \mathrm{C}$ (Thakaeng et al., 2020). Surprisingly, the value of PV of Pa butter was decreased by half and reached $0.31 \mathrm{meq} / \mathrm{kg}$ in groups of $12.5 \%$ and $17.5 \%$ Ag-LDPE films, respectively, showing a sensible decrease in oxidation level compared to other groups and Tr butter samples (Table 4). Similarly, the PV of the butter remained relatively stable, with increasing storage time up to one month in butter treated with WHE $0.5 \%$ at refrigerated temperature (Mehdizadeh et al., 2019).

In Table 4 , there is an apparent decrease $(\mathrm{p}<0.05)$ of melting point in Pa butter after $30 \mathrm{~d}$ while the butters were wrapping with 12.5 and $17.5 \% \mathrm{Ag} / \mathrm{LDPE}$ films (27.0 and $28.0^{\circ} \mathrm{C}$, respectively) in which the melting point were 29.0 and $30.0^{\circ} \mathrm{C}$, respectively at the beginning of the study. There was no significant difference $(\mathrm{p}>0.05)$ between the melting points of Tr butters on days 1 and 30. The butter stability can be improved by a higher melting point $\left(34^{\circ} \mathrm{C}\right)$ fractions from milk fat against low melting points butters (Schäffer et al., 2001). Analysis of the fat content and FFA profile of the Tr butter showed a greater melting point, and firmer in consistency that made it to be melted at higher points similar to yak butter (Neupaney et al., 2003), illustrating the higher melting point $\left(41^{\circ} \mathrm{C}\right)$ could be due to more significant fractions (58.35\%) of palmitic acid and stearic acid, which relatively were dissimilar compared to this study showed its fraction was $45.44 \%$ and $47.09 \%$, respectively for $\mathrm{Pa}$ and $\mathrm{Tr}$ butters (Table 4 ). The melting point of all butter samples dropped from 34.2 to $29.5^{\circ} \mathrm{C}$ when up to $25 \%$ Salvia hispanica (chia) oil was gradually mixed with butter oil. Chia oil has a significant proportion of Omega-3 and 6 Fatty Acids (Rahman et al., 2015).
The iodine value of analyzed for both butters was given in Table 4. The iodine value of the $\mathrm{Pa}$ and $\mathrm{Tr}$ butter in control (31.29 and 29.56, respectively $\mathrm{I}_{2} \mathrm{~g} / 100 \mathrm{~g}$ ) showed no significant difference $(p>0.05)$ compared to other groups (Table 4$)$. Initially, the Pa butters were insignificantly $(p>0.05)$ shown greater iodine value than Ta butter in the same group. Except for Tr butters wrapped with 7.5 and $17.5 \% \mathrm{Ag} / \mathrm{LDPE}$, which their iodine values respectively were decreased to 27.83 and $25.26 \mathrm{I}_{2} \mathrm{~g} / 100 \mathrm{~g}$ after $30 \mathrm{~d}$, Iodine values were not changed after $30 \mathrm{~d}$ either for $\mathrm{Pa}$ or Ta butters (Table 4). The greater the iodine value, the more unsaturated fatty acids or greater double-bond number are present in the butter oil results in a decrease of melting point (Naghshineh et al., 2010), which is in agreement with the Pa butters showing greater iodine values ( 30.32 vs 28.92 , respectively for $\mathrm{Pa}$ and $\mathrm{Tr}$ butters wrapped with $17.5 \% \mathrm{Ag} / \mathrm{LDPE}$ films) with lower melting point $\left(30^{\circ} \mathrm{C}\right)$. The iodine index of whey butter was higher with a lower melting point $\left(31.2^{\circ} \mathrm{C}\right)$ than regular butter $\left(34.5^{\circ} \mathrm{C}\right)$, which was due to the more significant proportion of unsaturated FA (Nadeem et al., 2015).

The acid value based on oleic acid (\%) is presented in Table 4. Initially, the acid values of $\mathrm{Pa}$ and $\mathrm{Tr}$ butters were respectively $0.19 \%$ and $0.14 \%$ with no significant difference ( $p>0.05$ ) compared to those of butters wrapped with 2.5-17.5\% $\mathrm{Ag} / \mathrm{LDPE}$ films or in comparison to the values of the thirtieth day at the same groups showing no hydrolysis of FFAs of the butters. The lipolytic property of oil was defined as the volume of FFA (as oleic acid\%), which was increased by hydrolysis of fat in the presence of water. The hydrolysis of fat was decreased over time due to moisture reduction (Koczoñ et al., 2008). In 
a research (Tafreshi et al., 2015), the iodine value showed an increase of 2-fold in Pa butter wrapped with any concentration of rosemary extract-polymeric film after two months of cold storage dissimilar to the butter exposed to gamma irradiation (Rady \& Badr, 2003) illustrated the acid value decreased by half reached $0.4 \%$ after one month against the result of this study (Table 4) showed no any changes in those of the acid value at the same time of storage. Since, the moisture value had no changes over the preservation, the stability of lipolytic activity could be due to the effect of Ag-LDPE films covered the butters (Table 2).

The main factors, which confirm fat quality, typical flavor, and odor in butters, are the saponification and acid values. The saponification value of $\mathrm{Pa}$ and $\mathrm{Tr}$ butters were 236.61 and $234.55 \mathrm{mg} \mathrm{KOH} / \mathrm{g}(\mathrm{p}>0.05)$ in the control showed no significant difference ( $p>0.05)$ compared to corresponding values of other groups. The values on the first day of cold storage insignificantly $(p>0.05)$ deceased on the thirtieth day, showing no remarkable difference in long-chain fatty acids (saturated and unsaturated) in both types of butters (Table 4). Long-chain FAs (saturated and unsaturated) are prone to be oxide and broken-down, which provides off-flavor and greater acid quantity showing the oxidation of triglycerides into FFA more generous in butter with high saponification values (Akhter et al., 2016).

\section{Conclusions}

It is concluded that LDPE film was produced in this study encompassed of the small size of nanosilver $(20.63 \mathrm{~nm})$ showed appropriate antimicrobial efficiency during cold storage up to 30d. Total bacteria, S. aureus, and E. coli were eliminated from the Pasteurized butters wrapped with $17.5 \% \mathrm{Ag} / \mathrm{LDPE}$ films. On the other hand, using psychrophilic bacteria can be eradicated with 2.5-17.5\% Ag/LDPE films, which can be important for prohibition the lipolytic and oxidation of fatty acids in butters. Using the 12.5-17.5\% Ag/LDPE films could significantly decrease peroxide value of pasteurized butter after $30 \mathrm{~d}$ of cold storage showing a reduction of oxidative rancidity of lipids. The melting point of pasteurized butter insignificantly reduced by 2 degrees while the $12.5 \%$ and $17.5 \% \mathrm{Ag} / \mathrm{LDPE}$ film were used. Greater iodine value showed that the use of $17.5 \% \mathrm{Ag} / \mathrm{LDPE}$ film increased saturated fatty acid and made the stability of traditional butter more than pasteurized one. Ultimately, the use of $17.5 \% \mathrm{Ag} / \mathrm{LDPE}$ as a coating of butter can safely preserve pasteurized butter at least a month of cold storage, but it does not recommend to use $\mathrm{Ag} / \mathrm{LDPE}$ film for protection of traditional butters.

\section{References}

Abebe, R., Hatiya, H., Abera, M., Megersa, B., \& Asmare, K. (2016). Bovine mastitis: prevalence, risk factors and isolation of Staphylococcus aureus in dairy herds at Hawassa milk shed, South Ethiopia. BMC Veterinary Research, 12(1), 270. http://dx.doi.org/10.1186/s12917016-0905-3. PMid:27912754.

Akhter, S., McDonald, M. A., \& Marriott, R. (2016). Mangifera sylvatica (Wild Mango): a new cocoa butter alternative. Scientific Reports, 6(1), 32050. http://dx.doi.org/10.1038/srep32050. PMid:27555345.

Al-Bachir, M., \& Othman, Y. (2019). Comparative studies on some physicochemical properties of oil extracted from gamma irradiated sesame (Sesamum indicum L.) seeds. J Food Chem Nanotechnol, 5(2), 36-42. http://dx.doi.org/10.17756/jfcn.2019-069.

Apjok, R., Cozmuta, A. M., Peter, A., Cozmuta, L. M., Nicula, C., Baia, M., \& Vulpoi, A. (2019). Active packaging based on cellulose-chitosan$\mathrm{Ag} / \mathrm{TiO} 2$ nanocomposite for storage of clarified butter. Cellulose, 26(3), 1923-1946. http://dx.doi.org/10.1007/s10570-018-02226-7.

Asdagh, A. A., \& Pirsa, S. (2020). Bacterial and oxidative control of local butter with smart/active film based on pectin/nanoclay/Carum copticum essential oils/ $\beta$-carotene. International Journal of Biological Macromolecules, 165(Pt A), 156-168. http://dx.doi.org/10.1016/j. ijbiomac.2020.09.192. PMid:32998015.

Ayar, A., Özcan, M., Akgül, A., \& Akin, N. (2001). Butter stability as affected by extracts of sage, rosemary and oregano. Journal of Food Lipids, 8(1), 15-25. http://dx.doi.org/10.1111/j.1745-4522.2001. tb00180.x.

Bali, O., Ammar, I., Ennouri, M., \& Attia, H. (2017). Physicochemical characteristics and storage stability of clarified butter fat «smen» produced from pasteurized and non-pasteurized milk. Journal of Pharmaceutical \& Health Sciences, 5(3), 195-205.

Bereda, A., Yilma, Z., \& Mitiku Eshetu, M. Y. (2018). Hygienic handling practices and quality of Ethiopian traditional butter (kibe) along the value chain in selected areas of the central highlands. Animal Production, 18(1), 59-74.

Bihon, A., Syoum, A., \& Assefa, A. (2019). Assessment of risk factors and isolation of Staphylococcus aureus and Escherichia coli from bovine subclinical mastitic milk in and around Gondar, Northwest Ethiopia. Tropical Animal Health and Production, 51(4), 939-948. http://dx.doi.org/10.1007/s11250-018-1777-2. PMid:30565186.

Cronin, T., Downey, L., Synnott, C., McSweeney, P., Kelly, E., Cahill, M., Ross, R. P., \& Stanton, C. (2007). Composition of ancient Irish bog butter. International Dairy Journal, 17(9), 1011-1020. http:// dx.doi.org/10.1016/j.idairyj.2007.01.012.

Dagdemir, E., Cakmakci, S., \& Gundogdu, E. (2009). Effect of Thymus haussknechtii and Origanum acutidens essential oils on the stability of cow milk butter. European Journal of Lipid Science and Technology, 111(11), 1118-1123. http://dx.doi.org/10.1002/ejlt.200800243.

Dirim, S. N., Özden, H. Ö., Bayındırlı, A., \& Esin, A. (2004). Modification of water vapour transfer rate of low density polyethylene films for food packaging. Journal of Food Engineering, 63(1), 9-13. http:// dx.doi.org/10.1016/S0260-8774(03)00276-0.

Elmonir, W., Abo-Remela, E., \& Sobeih, A. (2018). Public health risks of Escherichia coli and Staphylococcus aureus in raw bovine milk sold in informal markets in Egypt. Journal of Infection in Developing Countries, 12(7), 533-541. http://dx.doi.org/10.3855/jidc.9509. PMid:31954002.

European Union. (1994, December 9). Council Regulation (EC) No. 2991/94 of 5 December 1994 laying down standards for spreadable fats. Official Journal of the European Communities (pp. 2-7), L 316.

Evers, J. M., Crawford, R. A., \& Kissling, R. C. (2003). Determination of moisture, solids-not-fat and fat-by-difference in butter using routine methods according to ISO 8851/IDF 191: an international collaborative study and a meta-analysis. International Dairy Journal, 13(1), 55-65. http://dx.doi.org/10.1016/S0958-6946(02)00142-5.

Feng, P., Weagant, S. D., Grant, M. A., Burkhardt, W., Shellfish, M., \& Water, B. (2002). BAM: enumeration of Escherichia coli and the coliform bacteria. In U.S. Food and Drug Administration - FDA (Ed.), Bacteriological analytical manual. Silver Spring: FDA.

Gazu, L., Eshete, T., \& Kassa, G. (2018). Physicochemical analysis and microbial quality of cow butter obtained from Menz district of Amhara region, Ethiopia. African Journal of Bacteriology Research, 10(3), 34-43. http://dx.doi.org/10.5897/JBR2018.0268. 
Goharshadi, E. K., \& Azizi-Toupkanloo, H. (2013). Silver colloid nanoparticles: ultrasound-assisted synthesis, electrical and rheological properties. Powder Technology, 237, 97-101. http://dx.doi.org/10.1016/j. powtec.2012.12.059.

Idoui, T., Benhamada, N., \& Leghouchi, E. (2010). Microbial quality, physicochemical characteristics and fatty acid composition of a traditional butter produced from cows' milk in East Algeria. Grasas $y$ Aceites, 61(3), 232-236. http://dx.doi.org/10.3989/gya.110209.

Institute of Standard and Industrial Research of Iran - ISIRI. (2012a). Determine the fat content of butter: guideline of general requirements for examination (No. 1255). Iran: ISIRI.

Institute of Standard and Industrial Research of Iran - ISIRI. (2012b). Bacterial count procedure (No. 5275). Iran: ISIRI.

Issa, R. A., AlHanash, H. B., Kaakul, T. E., AlKout, R., \& Alkmishi, H. (2017). An investigation on Libyan olive oil in the western region. Moroccan Journal of Chemistry, 5(4), 2652-2658.

Jeong, Y., Lim, D. W., \& Choi, J. (2014). Assessment of size-dependent antimicrobial and cytotoxic properties of silver nanoparticles. Advances in Materials Science and Engineering, 2014, 1-6. http:// dx.doi.org/10.1155/2014/763807.

Jokar, M., Abdul Rahman, R., Ibrahim, N. A., Abdullah, L. C., \& Tan, C. P. (2012). Melt production and antimicrobial efficiency of lowdensity polyethylene (LDPE)-silver nanocomposite film. Food and Bioprocess Technology, 5(2), 719-728. http://dx.doi.org/10.1007/ s11947-010-0329-1.

Kadariya, J., Smith, T. C., \& Thapaliya, D. (2014). Staphylococcus aureus and staphylococcal food-borne disease: an ongoing challenge in public health. BioMed Research International, 2014, 827965. http:// dx.doi.org/10.1155/2014/827965. PMid:24804250.

Kaltsum, U., Kurniawan, A. F., Nurhasanah, I., \& Priyono, P. (2016). Reduction of peroxide value and free fatty acid value of used frying oil using TiO2 thin film photocatalyst. Bulletin of Chemical Reaction Engineering \& Catalysis, 11(3), 369-375. http://dx.doi.org/10.9767/ bcrec.11.3.577.369-375.

Karaman, A., Özer, B., Pascall, M. A., \& Alvarez, V. (2015). Recent advances in dairy packaging. Food Reviews International, 31(4), 295-318. http://dx.doi.org/10.1080/87559129.2015.1015138.

Khan, Z., Al-Thabaiti, S. A., Obaid, A. Y., \& Al-Youbi, A. (2011). Preparation and characterization of silver nanoparticles by chemical reduction method. Colloids and Surfaces. B, Biointerfaces, 82(2), 513517. http://dx.doi.org/10.1016/j.colsurfb.2010.10.008. PMid:21050730.

Koczoñ, P., Gruczyñska, E., \& Kowalski, B. (2008). Changes in the acid value of butter during storage at different temperatures as assessed by standard methods or by FT-IR spectroscopy. American Journal of Food Technology, 3(3), 154-163. http://dx.doi.org/10.3923/ajft.2008.154.163.

Krause, A., Miracle, R., Sanders, T., Dean, L., \& Drake, M. (2008). The effect of refrigerated and frozen storage on butter flavor and texture. Journal of Dairy Science, 91(2), 455-465. http://dx.doi.org/10.3168/ jds.2007-0717. PMid:18218731.

Martins, N. C. T., Freire, C. S. R., Pinto, R. J. B., Fernandes, S. C. M., Pascoal, C. No., Silvestre, A. J. D., Causio, J., Baldi, G., Sadocco, P., \& Trindade, T. (2012). Electrostatic assembly of Ag nanoparticles onto nanofibrillated cellulose for antibacterial paper products. Cellulose (London, England), 19(4), 1425-1436. http://dx.doi.org/10.1007/ s10570-012-9713-5.

Mehdizadeh, T., Mohammadipour, N., Langroodi, A. M., \& Raeisi, M. (2019). Effect of walnut kernel septum membranes hydroalcoholic extract on the shelf life of traditional butter. Heliyon, 5(3), e01296. http://dx.doi.org/10.1016/j.heliyon.2019.e01296. PMid:31025004.
Mofid, V., Mousavi, M., Emam-Djomeh, Z., Razavi, S. H., Gharibzahedi, S. M. T., \& Jahanbakhsh, F. (2018). Rheological characterization of functional walnut oil-enriched butters stabilized by the various polysaccharides. Journal of Dispersion Science and Technology, 39(4), 469-477. http://dx.doi.org/10.1080/01932691.2013.866576.

Morgan, J. A., Hoet, A. E., Wittum, T. E., Monahan, C. M., \& Martin, J. F. (2008). Reduction of pathogen indicator organisms in dairy wastewater using an ecological treatment system. Journal of Environmental Quality, 37(1), 272-279. http://dx.doi.org/10.2134/ jeq2007.0120. PMid:18178901.

Morones-Ramirez, J. R., Winkler, J. A., Spina, C. S., \& Collins, J. J. (2013). Silver enhances antibiotic activity against gram-negative bacteria. Science Translational Medicine, 5(190), 190ra81. http:// dx.doi.org/10.1126/scitranslmed.3006276. PMid:23785037.

Nadeem, M., Mahud, A., Imran, M., \& Khalique, A. (2015). Enhancement of the oxidative stability of whey butter through almond (Prunus dulcis) Peel Extract. Journal of Food Processing and Preservation, 39(6), 591-598. http://dx.doi.org/10.1111/jfpp.12265.

Naghshineh, M., Ariffin, A. A., Ghazali, H. M., Mirhosseini, H., \& Mohammad, A. S. (2010). Effect of saturated/unsaturated fatty acid ratio on physicochemical properties of palm olein-olive oil blend. Journal of the American Oil Chemists' Society, 87(3), 255-262. http:// dx.doi.org/10.1007/s11746-009-1495-z.

Neupaney, D., Kim, J., Ishioroshi, M., \& Samejima, K. (2003). Study on some functional and compositional properties of yak butter lipid. Animal Science Journal, 74(5), 391-397. http://dx.doi.org/10.1046/ j.1344-3941.2003.00131.x.

Poolman, J. T., \& Wacker, M. (2016). Extraintestinal pathogenic Escherichia coli, a common human pathogen: challenges for vaccine development and progress in the field. The Journal of Infectious Diseases, 213(1), 6-13. http://dx.doi.org/10.1093/infdis/jiv429. PMid:26333944.

Rady, A., \& Badr, H. (2003). Keeping the quality of cows' butter by $\gamma$-irradiation. Grasas y Aceites, 54(4), 410-418. http://dx.doi. org/10.3989/gya.2003.v54.i4.229.

Rahimi, E. (2013). Enterotoxigenicity of Staphylococcus aureus isolated from traditional and commercial dairy products marketed in Iran. Brazilian Journal of Microbiology, 44(2), 393-399. http://dx.doi. org/10.1590/S1517-83822013000200008. PMid:24294227.

Rahman, F., Nadeem, M., Ajmal, M., \& Ayaz, M. (2015). Analytical characterization of butter oil enriched with omega-3 and 6 fatty acids through chia (Salvia hispanica L.) seed oil. Pakistan Journal of Analytical \& Environmental Chemistry, 16(2), 4.

Samet-Bali, O., Ayadi, M., \& Attia, H. (2009). Traditional Tunisian butter: physicochemical and microbial characteristics and storage stability of the oil fraction. Lebensmittel-Wissenschaft + Technologie, 42(4), 899-905. http://dx.doi.org/10.1016/j.lwt.2008.11.007.

São José, J. F. B., Medeiros, H. S., Oliveira, F. C. E., Fialho e Moraes, A. R., Oliveira, D. S., Medeiros, É. A. A., \& Soares, N. F. F. (2019). Development and characterization of active film with omega- 3 as a proposal for enrichment of butter. Food Science and Technology, 39(Suppl. 1), 304-308. http://dx.doi.org/10.1590/fst.00618.

Sarab, M. L., Nouri, M., \& Tarighat-Esfanjani, A. (2019). Characteristics of Iranian traditional butter produced in Sarab in comparison with European and national standards. Progress in Nutrition, 21, 416-421.

Schäffer, B., Szakály, S., Lőrinczy, D., \& Schäffer, B. (2001). Melting properties of butter fat and the consistency of butter. Effect of modification of cream ripening and fatty acid composition. Journal of Thermal Analysis and Calorimetry, 64(2), 659-669. http://dx.doi. org/10.1023/A:1011579924951. 
Shi, T., Sun, X., \& He, Q.-Y. (2018). Cytotoxicity of silver nanoparticles against bacteria and tumor cells. Current Protein \& Peptide Science, 19(6), 525-536. http://dx.doi.org/10.2174/13892037186661611080 92149. PMid:27829349.

Shrivash, M. K., Mishra, S., UpmaNarain, Pandey, J., \& Misra, K. (2018). In-silico designing, chemical synthesis, characterization and in-vitro assessment of antibacterial properties of some analogues of curcumin. Microbial Pathogenesis, 123, 89-97. http://dx.doi. org/10.1016/j.micpath.2018.06.030. PMid:29959040.

Silva-Kazama, D. C., Santos, G. T., Pintro, P. T. M., Visentainer, J. V., Kazama, R., Petit, H. V., \& Marchi, F. E. (2010). Effect of storage on fatty acid profile of butter from cows fed whole or ground flaxseed with or without monensin. Revista Brasileira de Zootecnia, 39(10), 2297-2303. http://dx.doi.org/10.1590/S1516-35982010001000028.

Simbine, E. O., Rodrigues, L. C., Lapa-Guimaraes, J., Kamimura, E. S., Corassin, C. H., \& Oliveira, C. A. F. (2019). Application of silver nanoparticles in food packages: a review. Food Science and Technology, 39(4), 793-802. http://dx.doi.org/10.1590/fst.36318.

Singh, P., Wani, A. A., Karim, A., \& Langowski, H.-C. (2012). The use of carbon dioxide in the processing and packaging of milk and dairy products: a review. International Journal of Dairy Technology, 65(2), 161-177. http://dx.doi.org/10.1111/j.1471-0307.2011.00744.x.

Tafreshi, F., Javanmard, M., \& Fahimdanesh, M. (2015). Effect of rosemay extract coated polymeric film (LDPE) for inhibition of butter oxidation. Majallah-i Pizhuhishha-Yi Ulum va Sanayi-i Ghazayi-i Iran, 11(2), 129-139.
Thakaeng, P., Wongsakul, S., \& Yusoff, M. M. (2020). Development of value-added butter through the addition of green tea (Camellia sinensis L.) extract. International Food Research Journal, 27(3), 465-474.

Tola, A., Bayu, D., Fita, L., Agza, B., \& Birkie, S. (2019). Microbial and organoleptic evaluation of traditional butter preservation techniques. Food Science and Nutrition Completed Research, 61. http://dx.doi. org/10.5897/AJFS2018.1709.

Van Dong, P., Ha, C. H., Binh, L. T., \& Kasbohm, J. (2012). Chemical synthesis and antibacterial activity of novel-shaped silver nanoparticles. International Nano Letters, 2(1), 9. http://dx.doi.org/10.1186/2228-5326-2-9.

Vazquez-Muñoz, R., Arellano-Jimenez, M. J., Lopez, F. D., \& Lopez-Ribot, J. L. (2019). Protocol optimization for a fast, simple and economical chemical reduction synthesis of antimicrobial silver nanoparticles in non-specialized facilities. BMC Research Notes, 12(1), 773. http:// dx.doi.org/10.1186/s13104-019-4813-z. PMid:31775864.

Wei, C., Zhong, J., Hu, T., \& Zhao, X. (2018). Simultaneous detection of Escherichia coli O157: H7, Staphylococcus aureus and Salmonella by multiplex PCR in milk. 3 Biotech, 8(1), 76. http://dx.doi.org/10.1007/ s13205-018-1086-5. PMid:29354387.

Yan, X., He, B., Liu, L., Qu, G., Shi, J., Hu, L., \& Jiang, G. (2018). Antibacterial mechanism of silver nanoparticles in Pseudomonas aeruginosa: proteomics approach. Metallomics, 10(4), 557-564. http:// dx.doi.org/10.1039/C7MT00328E. PMid:29637212.

Zhao, X., Wei, C., Zhong, J., \& Jin, S. (2016). Research advance in rapid detection of foodborne Staphylococcus aureus. Biotechnology, Biotechnological Equipment, 30(5), 827-833. http://dx.doi.org/10.1 080/13102818.2016.1209433. 